J. Product. \& Dev., 23(1): 157-175(2018)

\title{
STUDIES ON EFFECT OF PROCESSING AND STORAGE ON Quality OF JAM PRODUCED FROM TOMATO (VARIETY HYPEEL.303).
}

\section{H.M. Khashaba ${ }^{1}$; Ibrahim I.M.A. ${ }^{1}$ and Azzazy M.B. ${ }^{2}$}

1. Special Food and Nutrition Department Food Technology Research Institute, Agriculture Research Center, Giza, Egypt .

2. Horticultural Products Technology Department Food Technology Research Institute, Agriculture Research Center, Giza, Egypt.

Corresponding author:hmicro369@yahoo.com,ibrahim256_mah@yahoo.com

\section{ABSTRACT}

Epidemiological data showed that tomato and tomato products (sauce, paste) it have a protective effect against the development of some chronic-degenerative diseases. Tomato has bioactive molecules such as carotenoids and polyphenols could be responsible for health effects. In this study, five jam mixtures were developed, at various compositions T1 (70-30), T2 (60-40), T3 (50-50), T4 (40-60) and T5 (30-70) of tomato pulp and sugar (sucrose). The aim of this study was to produce a good product of tomato jam characterized with high nutritional value and quality. Tomato jam is not produced commercially in Egypt yet. In order to the chemical, physical and sensory quality indices of the produced jam samples were measured. The results showed the superiority of (T2) treatment compared to the other treatments in terms of TSS, pH, acidity, color index, total phenol, vitamin C (Ascorbic acid), carotenoids, lycopene, antioxidant activity, color parameters and sensory attributes. The treatment (T3) came in the second position followed by the treatment (T1), while both of the treatments (T5) and (T4) recorded the worst results.

Conclusively, it is concluded that attention must be paid to increasing the production of tomato jam for commercial scale by proposed rate in order to healthy benefits, high acceptance and higher nutritional values with introduced it regularly in some main meals like breakfast and dinner, mainly due to their health benefits.

Key words: Processing, Storage, Quality Of Jam Produced, Tomato 


\section{INTRODUCTION}

Oxidative stress is characterized by an imbalance between antioxidant capacity and reactive oxygen species (ROS) generation. Overproduction of ROS increases during aging and contributes too many pathological events such as cancer and cardiovascular diseases. A lack of nutritional antioxidants, such as vitamin E, vitamin C (Ascorbic acid), polyphenols and carotenoids can contribute to oxidative stress generation. Tomatoes are a good source of lycopene, $\beta$-carotene and polyphenolic compounds, such as flavonoids and hydroxycinnamic acids. Among them, naringenin (flavanone) and chlorogenic acid (hydroxycinnamic acid) are the most abundant (Davies and Graeme, 1981). Recent epidemiologic studies focusing on tomato and tomato products associated their intake with a reduced risk of degenerative diseases (Giovannucci et al., 1995). High intake of tomato juice prevents low density lipoproteins (LDL) oxidation and thiobarbituric reactive species (TBARS) formation in healthy men (Bub et al., 2000). Lycopene and $\beta$-carotene are the most prevalent carotenoid pigments in tomatoes, lycopene content being more than tenfold higher than $\beta$-carotene. Tomatoes are the main source of lycopene in the human diet, containing between $40-180 \mathrm{mg} / \mathrm{kg}$ (fresh weight) (Davies and Graeme, 1981). Both lycopene and $\beta$-carotene exert antioxidant properties in vitro, acting as 102 quenchers and radical trapping agents (Hoober, 1984). Beta-carotene serves as an important source of vitamin A, while recent epidemiological data show a significant effect of lycopene intake on reduce the incidence of prostate and gastrointestinal tract cancers (Clinton, 1998). Individual compounds found to be significantly related to antioxidant capacity are lycopene and ferulic and caffeic acids in tomato (Marti'nez-Valverde et al., 2002). Lycopene also exerts direct anticarcinogenic effects including up regulation of gap-junction communication (Hart and Scott, 1995) and modulation of growth factors such as insulin-like growth factor 1(IGF-1) or cytokines like interleukin 6 (Il-6) (Siler et al., 2005). Blood lycopene levels were inversely correlated with prostate cancer and cardiovascular (Giovannucci and Clinton, 1998 and Clinton, 1998). Lycopene, through tomato sauce consumption, reduces leukocyte and prostate tissue oxidative DNA damage and decreases prostate specific antigen (PSA) level in prostate cancer patients (Chen et al., 2001). Many population studies have established a link between dietary intake of tomatoes, a major source of the antioxidant lycopene, and a reduced risk of cancer and cardiovascular diseases (Agarwa and Rao, 2000). In animal prostate cancer models, tomato supplementation showed 
higher effects than lycopene supplementation on carcinogenesis prevention and mortality (Imaida et al., 2001 and Boileau et al., 2003). In addition to lycopene, violaxanthin, neoxanthin, lutein, zeaxanthin, a-cryptoxanthin, b-

cryptoxanthin, a-carotene, b-carotene, g-carotene, z-carotene, neurosporene, phytoene, phytofluene, cyclolycopene and b-carotene 5,6epoxide are other carotenoids commonly cited in tomato and tomatoderived products (Fraser et al.,1994; Paetau et al.,1998; Khachik et al., 2002 and Burns et al.,2003). Among these, $\alpha$-carotene, b-carotene and bcryptoxanthin have pro-vitamin A activity, since they are converted to retinal by mammals (Burns et al., 2003).

Therefore, the aim of this study was to produce a good product of tomato jam which giving the attention of manufacturers to produce it on a large scales due to its nutritional value and quality which reduced risk of degenerative diseases. Tomato jam is not produced commercially in Egypt yet. This research was aimed also to evaluate effect of processing and storage on the chemical composition and sensory attributed of tomato puree and jam.

\section{MATERIALS AND METHODS}

\section{Materials}

Fresh tomato (Lycopersicum esculentum; variety Hypeel.303), purchased from private farm in New Salhia Governorate, Egypt. Commercially available sucrose was used in the jam manufacturing. Citric acid, pectin (apple pectin) and sodium benzoate were obtained from ElGomhoria Company.

\section{Methods}

\subsection{Preparation of Jams}

Tomato at the ripe stage were washed and cut into small parts. Tomato were extracted by (Moulinex T574, France), where it took five minutes blending to get the tomato juice. The juice was strained by stainless steel strainer, then strained by clean muslin cloth to get rid of seeds and peels for obtaining puree tomato juice. After seed and fiber remove tomato puree was mixed with sucrose at ratios of T1 (70-30), T2 (60-40), T3 (50$50), \mathrm{T} 4$ (40-60) and T5 (30-70) and allowed to stay at room temperature for 45 min (no water was added). The different treatments were treated with citric acid $(1 \%)$, sodium benzoate $(0.1 \%)$ and pectin was added $(1$ or $2 \%$ over tomato weight). The mixtures were heated to boiling and $1 \%$ citric acid was added to improve taste. Heating continued for 15-20 min. Then pectin 
was added and the heating continued. When, total soluble solids were reached to $68 \%$, the produced jams were hot filled into glass bottles. Finally, the jars hermetically closed which cooled to $20-30^{\circ} \mathrm{C}$ and stored at room temperature. The production was duplicated, and all physical, chemical and sensory measurements were adopted and results were compared.

\subsection{Chemical Analysis}

Total soluble solids (TSS), pH, total titratable acidity, ascorbic acid content and total \& reducing sugars were analyzed according to methods described by the A.O.A.C. (2005). Alcohol soluble color (ASC) was determined according to the methods described by Ranganna (1979). Color attributes (L, a and b) were evaluated according to Francis (1980) using a Minolta color Reader (CR-10, Minolta Co. Ltd., Japan.). Total phenolic content of jam was determined spectrophotometrically (a spectrophotometer model PU 8625) using the Folin and Ciocalteu assay described by Vinson et al.,(1995). Carotenoids were determined according to Bandyopadhyay et al.,(2008), while lycopene was determined according to Barrett and Anthon (2001). Radical-Scavenging activity was measured according to the method of Brand-Williams et al.,(1995). Sensory evaluation of the different tested jams were carried out using the method of Howard and Dewi (1995) by ten staff members (semi trained panelists) for taste (10), flavor (10), texture (10), mouthfeel (10) and sweetness (10).The overall acceptability was calculated from the total scores of the tested attributes.

Data was analyzed statistically according to the methods described by Snedecor and Cochran (1980).

\section{RESULTS AND DISCUSSION}

Data presented in Figure (1) illustrated brix, pH, acidity and ASC contents of tomato jam samples at zero time and after storage for 6 months at ambient temperature. From the figure it is clear that the TSS values were equivalent $(68 \%)$ in the beginning of the storage at zero time. In order to form a stable pectin-acid gel network, there must be some level of soluble solids present in the milieu. In addition, degree of Brix is usually regulated by product regulations or standards. According to, (Anonymous, 2002) requires at least $68 \%$ Brix for the 'traditional type' jam products. At the end of storage T2 and T1 treatments recorded the fewer rate of change in TSS\% compared with other treatments. Generally, T5 recorded the highest decline by the end of storage after 6 months at room temperature. 

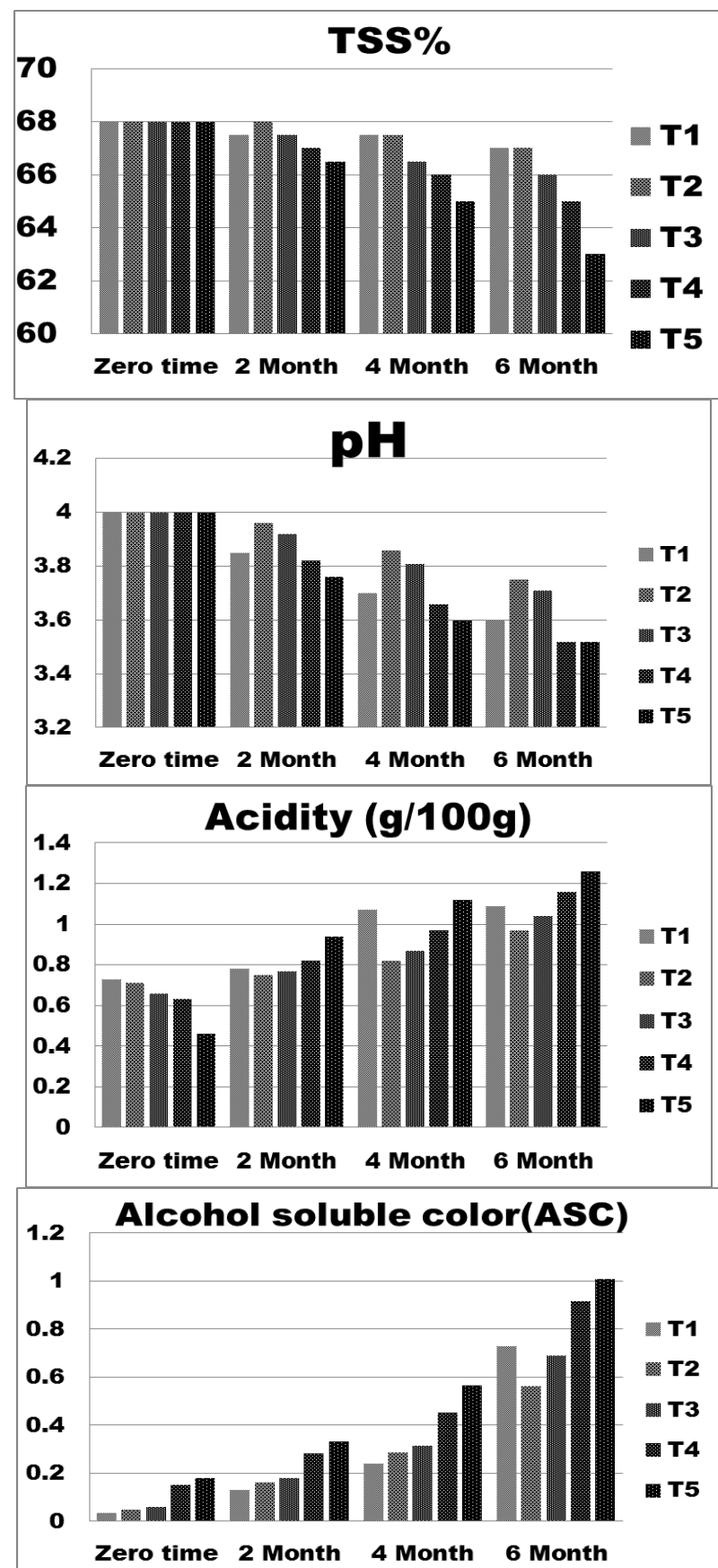

Figure (1): Effect of storage on TSS, pH, Acidity and ASC in different treatments of tomato jams. 
It's clear from the data in the Figure (1) that, $\mathrm{pH}$ values of all treatments have the similar value at zero time, although $\mathrm{pH}$ values decreased progressively during storage this refers to chemical changes in the product during storage which lead to increasing the acidity. Ehsan et al., (2002) observed same trend in mixed fruit jam prepared from watermelon (fleshy part) and lemon. Similarly, reduction in $\mathrm{pH}$ of jam prepared from grape fruit and apple was reported by Iftikhar et al., (2007). The results generally show that the sample (T2) recorded the lowest rate of change in the $\mathrm{pH}$ and acidity at the end of storage. The sample (T5) gave the lowest $\mathrm{pH}$ value and the higher increment in acidity. The reduction in $\mathrm{pH}$ values can be noticed in all samples at the end of storage while, acidity was increased in all samples by end of storage. It could be noticed that there is a relation between $\mathrm{pH}$ value and titratable acidity, which is inversely proportional as seen in Figure (1). The same results obtained by Sogi and Singh, (2001) who found that $\mathrm{pH}$ range of watermelon rind jams showed a movement towards acidity over the storage period. The general decrease in $\mathrm{pH}$ (more acidic) might be due to ascorbic acid degradation, hydrolysis of pectin and other acidic compounds such as furfural development from sugar components Imtiaz and Iftikhar, (2010). There was a positive correlation between increasing $\mathrm{pH}$ value of jams and increasing preferable taste. The first three treatments gave preferable taste and flavor compared to the last two treatments with end of storage. On the other hand to set a stable gel, and to form enough acidity in taste, there should be $0.3-1.5 \%$ total acidity in jam products. Depending on the fruit's natural acid level and added acid, total acidity can be arranged easily. As mid-high acid fruits, tomato jams have yielded enough acidity with a very goodly balanced sweet-sour taste (Bowler et al., 1995; Broomfield, 1996 and Anonymous, 2002).

ASC indices increase by increasing sugar level in sample after processing at zero time. After 6 month storage at ambient temperature, the ASC index was gradually increased in all treatments, but the most increase recorded in the sample (T5) (70 sugar: 30 puree) tracked by in the sample (T4), respectively. The slightest ASC indexes were recorded in the samples (T2 and T3).

The assessed data of carotenoids characterized with a decline in the estimated values after treated at zero time, this decrease proportionate positively with the quantity of tomato puree on the sample. This relationship had vanished with the continued storage, the first treatment, which contains the highest amount of pulp becoming in third place in terms of the amount of carotene at the end of storage. Although, it has outperformed both the second 


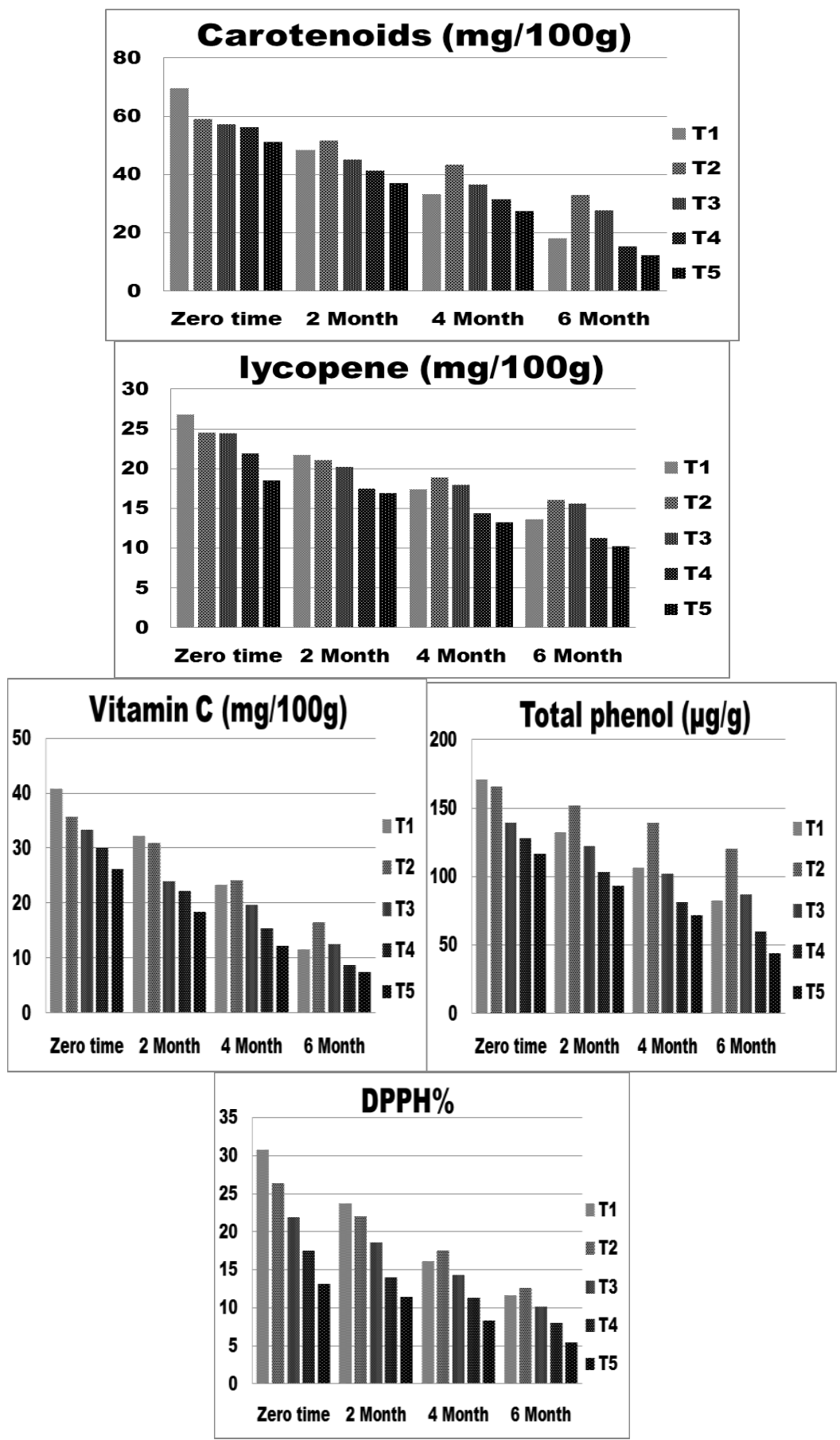

Figure (2): Effect of storage on Carotenoids, lycopene, Vitamin C, Total phenols and DPPH in different treatments of tomato jams. 
and third treatments, while fifth treatment came in last place in terms of carotenoids content in the samples.

Lycopene is one of the most important antioxidant which removes the free radicals from the body, which cause oxidative stress, the body liver enzymes failure occurs and the body become vulnerable with serious diseases such as cancer and cardiac diseases. Lycopene-rich food is inversely associated to diseases such as cancers, cardiovascular diseases, diabetes and others diseases Kong et al., (2010). The assessing results evidenced that there is a positive correlation between lycopene content and quantity of tomato puree in the sample at zero time. The second treatment was outperformed on the others treatments in terms of lycopene content and followed by the third treatment while, the fifth treatment came in last place (10.29 mg/100g).

As can be seen in Figure (2) that the deficiency in vitamin $\mathrm{C}$ content were detected from in the samples (T1 to T5) at zero time. Also, the results refer to the superiority of second and third treatments at the end of storage, respectively. However, there has been a decline in the value of the vitamin $\mathrm{C}$ in the samples (T5 and T4). The results agree with Jawaheer et al., (2003) who reported that ascorbic acid content of the jam products were decreased during storage period. It may due to oxidation of ascorbic acid.

Analysis of total phenols content of tomato jam at zero time illustrated that sample (T1) $(170.89 \mu \mathrm{g} / \mathrm{g})$ had the maximum value and the value of total phenols were decrease gradually from the sample (T1) to (T5) as in order. During storage the total phenols were decreased in sample progressively, in the sample (T5) which contained $(44.24 \mu \mathrm{g} / \mathrm{g}$ ) this content was decreased by storage followed the sample (T4) which contained $(59.60 \mu \mathrm{g} / \mathrm{g})$ while, the sample (T2) keep with the highest content compared with the other treatments.

Analysis of jams at zero time showed the correlation between the antioxidant activity and all compounds characterized with antioxidant activity such as carotenoids, lycopene, vitamin $\mathrm{C}$ and total phenols. It has been noted before that together with phenolic compounds, ascorbic acid represents the main water-soluble antioxidant in tomatoes and contributes to the antioxidant activity of the water-soluble fraction (Raffo et al., 2002). Another author indicates that antioxidant properties of tomatoes depend largely on lycopene content (Mart1 'nez-Valverde et al., 2002). 


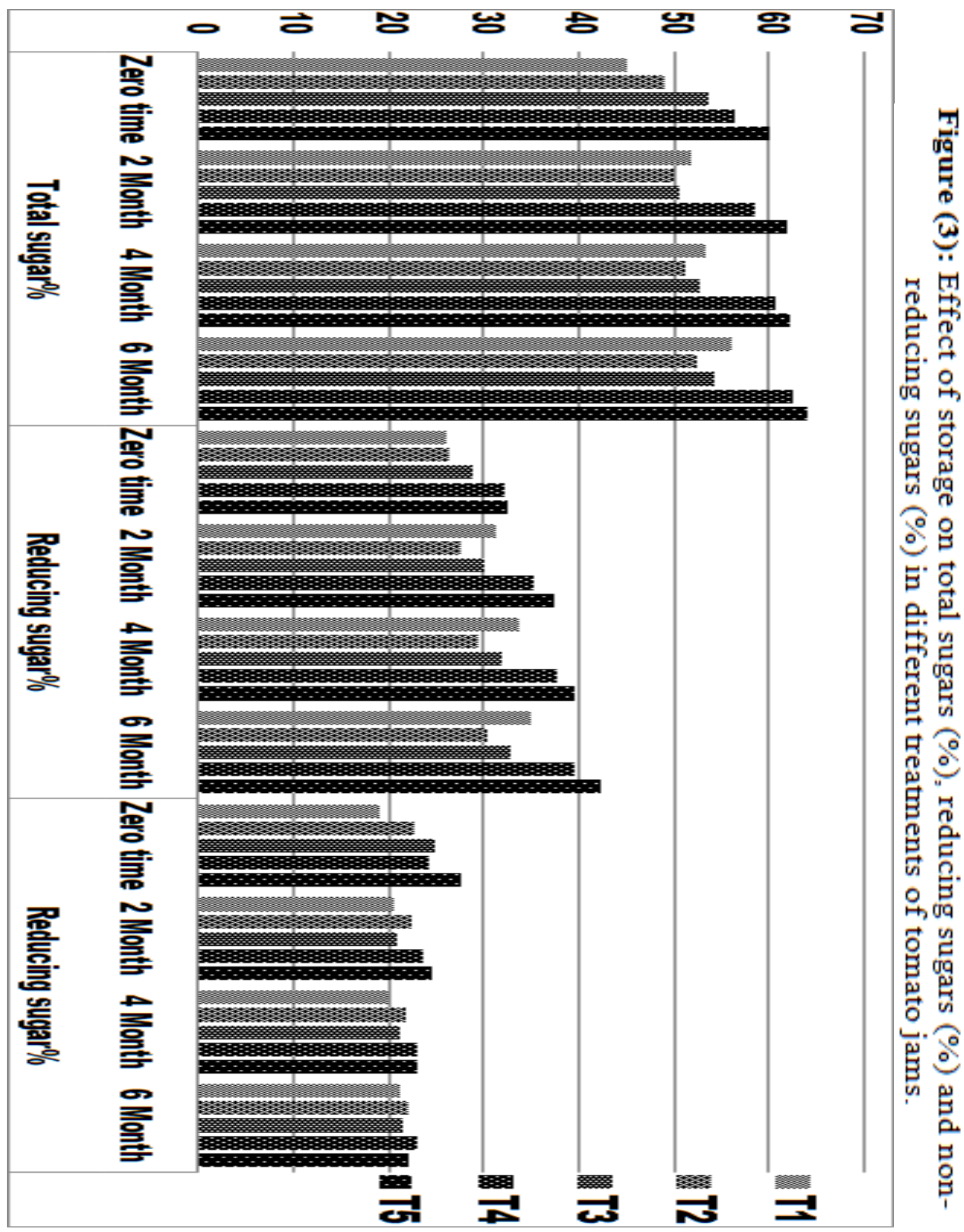


Thus, in considering the large amounts of vitamin $\mathrm{C}$ and lycopene it contain, it would be expected that tomato jams have a higher antioxidant activity. (DPPH) values characterized by drop in their values as the arranged begin from the sample (T1) and ending with the sample (T5). After 6 months of storage at ambient temperature, all treatments exhibited higher alterations in (DPPH) activity however, the sample (T2) recorded the higher activity rate followed by the sample (T3) then sample (T1) while, the samples (T5 and T4) recorded the lower activity between the tested samples.

Data existing in Figure (3) showed the content of total, reducing, non reducing sugar in tomato jams. The trend of total sugars data appeared the increment of determined values of total sugars with increase content of sugar addition to sample at zero time. During storage all jams recorded noticeable increase in total sugar (sucrose) but the sample (T2) documented the lowest increase $(52.21 \%)$, this may be due to the lower changes in chemical composition.

The content of reducing sugar increase from the samples (T1 to T5), this trend of result was appropriate with quantity of sugar addition. The sample (T2) keep with the lowest change in reducing sugars at the end of storage so as to this treatment recorded the lower browning compared to all treatments and higher rate of lightning at the end of storage. This may be due to less oxidation.

At zero time the identified levels of non-reducing sugar were increased from the treatment (T1) to the treatment (T5), respectively. At the end of storage the non-reducing sugars were decreased in all treatments. The lower degradation in total sugars was noticed in the treatment (T2) which had a higher content of non-reducing sugars. The greatest alternation in total sugars was noticed in the treatments (T5 and T4) followed by the treatment (T1).

Effect of processing and storage on hunter $\mathrm{L}, \mathrm{a}, \mathrm{b}$ values are shown in Figure (4). Data indicating that the treatment (T2) had higher lightening value (31.2) compared with all treatments at zero time followed by the treatment (T3) then the treatment (T1) while, the treatment (T5) recorded the highest darkening followed by the treatment (T4). The same lightening ordered of sample retained with it at the end of storage compared with data at zero time.

Color is one of important quality properties of the fresh fruits used in jam manufacture. Hence, care must be taken both during processing and storage (Broomfield, 1996; Chiralt \& Martinez-Navarrete, 2002 and Schieber $\&$ Carle, 2005). 


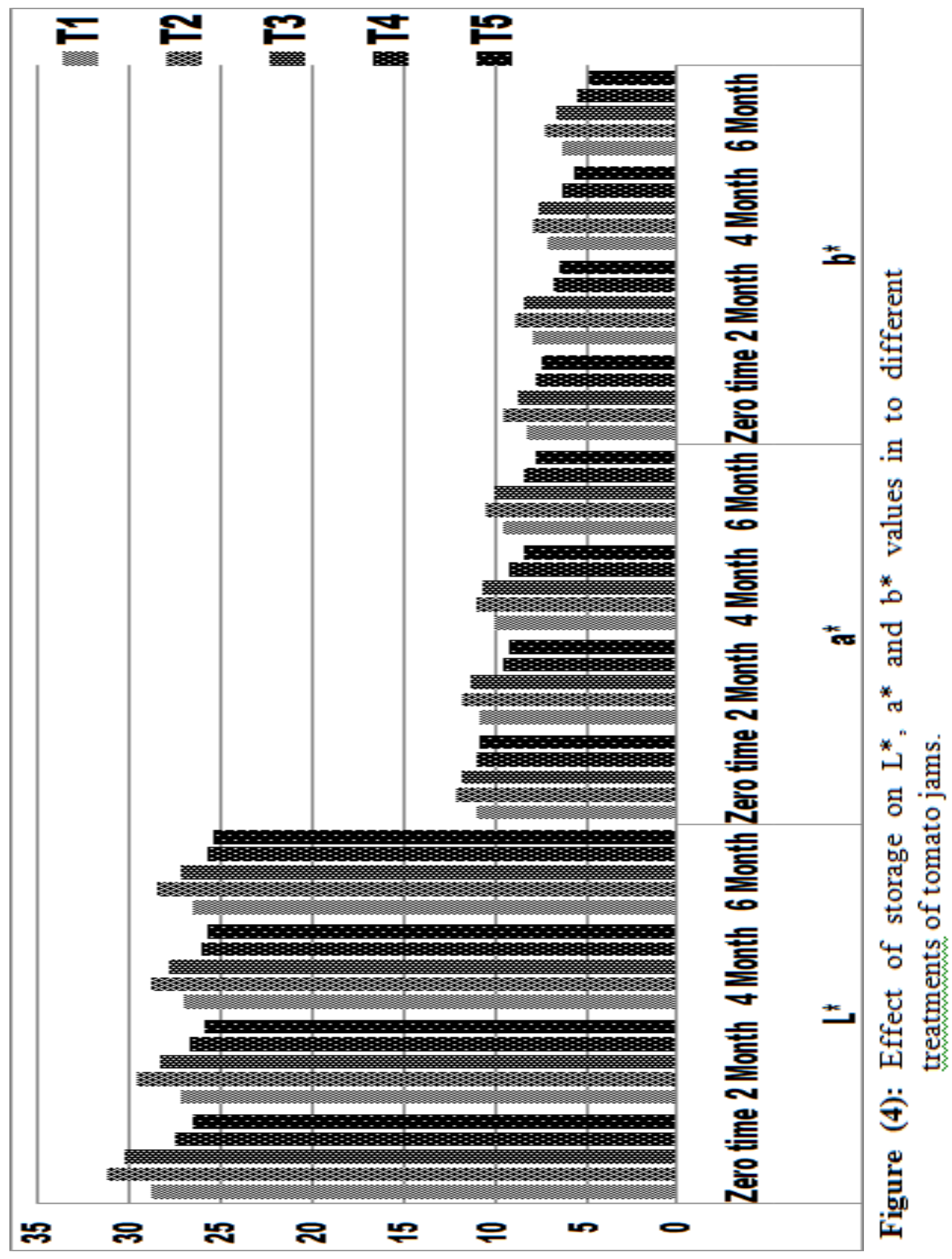


Hunter $a^{*}$ values (redness) are also shown in Figure (4). These values refer to the content of lycopene or chlorophyll content in the product. The lower value of $a^{*}$ indicate the higher level for chlorophyll which refer to the lower level of quality and increase of the darkening as a result of browning happened after heating and pasteurization of the product. Also, the rate of black spots was increased by increasing of the green color of chlorophyll. The higher content of $\mathrm{a}^{*}$ value refer to the elevated content of lycopene pigment on product which refer to the higher quality of jam and elevated antioxidant activity in the product. $b^{*}$ values refer to the level of yellow or orange pigment as indicate to carotenoids pigment at $(+)$ axis while, (-) axis refer to blue color. The treatment (T2) appeared the higher content of lycopene at zero time pursued by the treatment (T3) then the treatments (T1 and T4) while, the treatment (T5) came at end of order. The same order had obtained at the end of storage, also the same order had obtained for $b^{*}$ value at the beginning and at the end of storage. These results confirm that treatment (T2) gained at all of treatments at the end of storage, which recorded higher level of quality compared with to other the treatments.

The higher value of Heu refer to retain the sample with the color but the lower value indicating to alteration or losing exhibited in color product. Chroma value had a good a measurement for color purity. The treatments (T2 and T3) were the more color intensity (Heu values) at zero time which reserved the ability of two treatments at retained with the color after manufacture. The maximum changes were recorded by the treatment (T5) followed by the treatment (T4). During storage, gradual degradation of Heu values was observed in both of the treatments (T5 and T4). Slight decrease in the color intensity after 6 months of storage was obtained in all treatments. The treatments (T2 and T3) recorded the lowest Heu changes at the end of storage. The same trend of results was obtained in Chroma values at start and the end of storage.

Taste is the most important properties of sensory attributes and together with flavor are the very critical factors for consumer acceptance and preference in these types of products. Hedonic texture was defined as 'the fruit in the jam should be in mid hardness, neither stony nor spongy'. Mouthfeel and sweetness are also very critical for consumer acceptance of jams. The overall preferences of panelists for the five treatments are shown in Figure (6).

The question to the panelists was 'which of the jam samples you prefer the most' and collected data converted to overall acceptability. The treatment (T2) was the most liked one with the degree (7.8) for overall acceptability at the end of storage. Secondly, the treatment (T3) recorded (7.4) for an acceptance rate followed by (T1) on the third order. In general, the treatments (T4 and T5) 


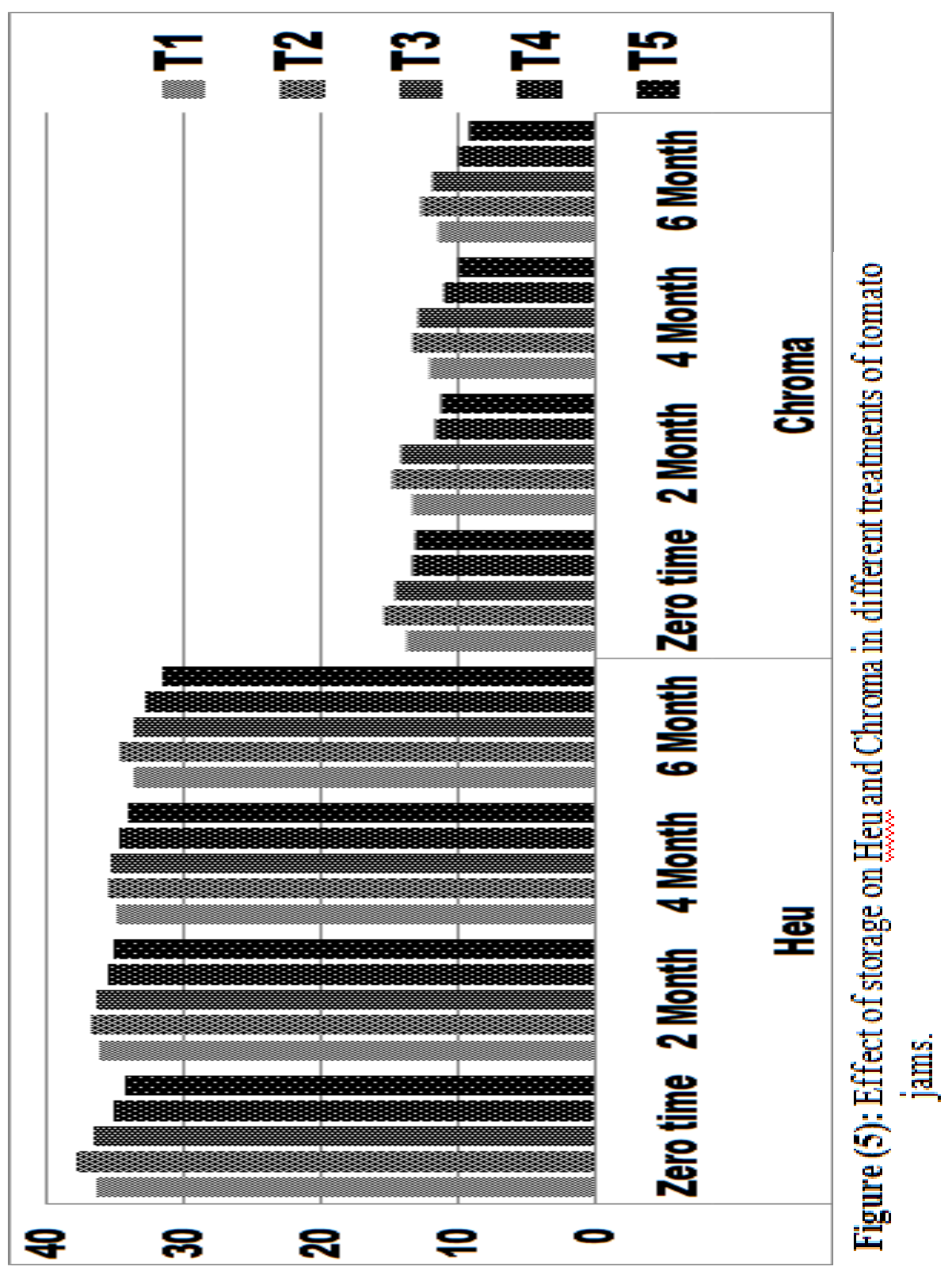




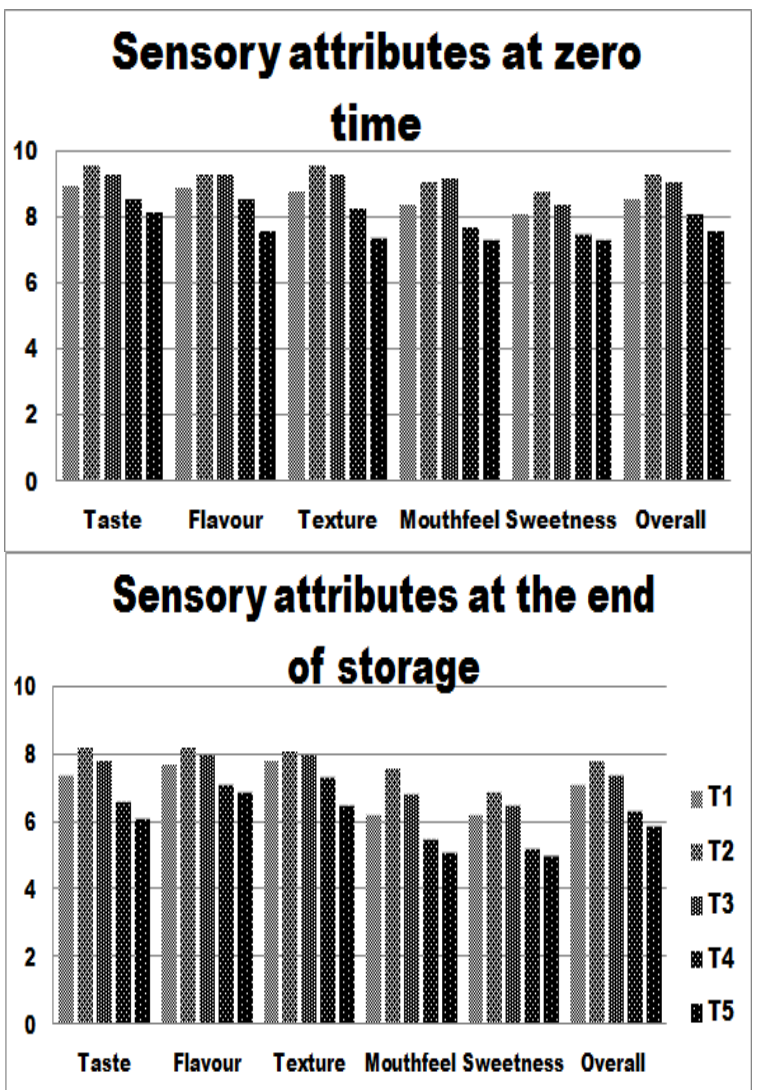

Figure (6): Sensory attributes of tomato jams at zero time and the end of storage.

recorded a lower level of quality compared with other treatments which make it unsuitable for industrial production.

Conclusively, in this study, five jam treatments were developed at various compositions the treatment T1 (70-30), the treatment T2 (60-40), the treatment T3 (50-50), the treatment T4 (40-60) and the treatment T5 (30-70) of tomato juice and sugar (sucrose). The superiority (T2) making this treatment suitable for industrial producing with large scale in order to higher quality, acceptance and nutritional values compared with other treatments. The treatment (T3) recorded less score of quality followed by the treatment (T1). On contrary the treatments (5 and 4) recorded the worst quality parameters and sensory attributes which was considered them unsuitable for commercial production. 


\section{REFERENCES}

A.O.A.C. (2005). Official Methods of Analysis of AOAC. International 18th Ed. Edited by Dr. William Horwiz. Published by AOAC International Suite 500. Gaithersburg, Maryland 20877-2417, USA.

Agarwa, I.A. and Rao, A.V. (2000). Tomato lycopene and its role in human health and chronic diseases. Canadian Medical Association Journa,l 163, 739-744.

Anonymous, (2002). Turkish Regulation of jams, marmalades and sweetened chestnut purees. (Official paper, Number 2002/10). State Gazette 16.02.2002. Ankara, Turkey.

Bandyopadhyay, M.; Chakraborty, R. and Raychaudhuri, U. (2008). Effect of beet and honey on quality improvement and carotene retention in a carrot fortified milk product. Innovative Food Science and Emerging Technologies, 9, 9e17.

Barrett, D.M. and Anthon, G.E. (2001). Lycopene content of californiagrown tomato varieties. Acta Horticulture, Vol. 542, No. 7, pp. 165174.

Boileau, T.W.; Liao, Z.; Kim, S.; Lemeshow, S.; Erdman, J.W. and Clinton, S.K. (2003). Prostate carcinogenesis in N-methylNnitrosourea (NMU)-testosterone-treated rats fed tomato powder, lycopene, or energy-restricted diets. J Natl Cancer Inst, 95:15781586.

Bowler, P.; Loh, V.Y. and Marsh, R.A. (1995). Preserves and jellies. In 'Physico-Chemical Aspects of Food Processing', ed. by S.T. Beckett, Blackie Academic \& Professional Pub, New York, pp. 315- 331.

Brand-Williams, W.; Cuvelier, M.E. and Berset, C. (1995). Antioxidative activity of phenolic composition of commercial extracts of sage and rosemary. LWT - Food Science and Technology, 28: $25-30$.

Broomfield, R.W. (1996). The manufacture of preserves, flavourings and dried fruits. In 'Fruit Processing', ed. by D. Arthey and P.R. Ashurt, Blackie Academic \& Professional Pub, New York, pp. 165-195.

Bub, A.; Watzl, B.; Abrahamse, L.; Delincee, H.; Adam, S.; Wever, J.; Muller, H. and Rechkemmer, G. (2000). Moderate intervention with carotenoid-rich vegetable products reduces lipid peroxidation in men. J. Nutr., 130:2200-2206. 
Burns, J.; Paul, D.; Fraser, P. and Bramley, M. (2003). Identification and quantification of carotenoids, tocopherols and chlorophylls in commonly consumed fruits and vegetables. Phytochemistry, 62, 939-947.

Chen, L.; Stacewicz-Sapuntzakis, M.; Duncan, C.; Sharifi, R.; Ghosh, L.; van Breemen, R.; Ashton, D.; and Bowen, P.E. (2001). Oxidative DNA damage in prostate cancer patients consuming tomato sauce-based entrees as a wholefood intervention. J. Nat. Cancer Inst., 93:1872-1879.

Chiralt, A. and Martinez-Navarrete N., (2002). Jam manufacture with osmodehydrated fruit. Food Res. Int. , 35: 301-306.

Clinton, S.K. (1998). Lycopene: chemistry, biology, and implications for human health and disease. Nutr. Rev., 56:35-51.

Davies, J.N. and Graeme, E.H. (1981) The constituents of tomato fruit the influence of environment, nutrition, and genotype. Crit Rev Food Sci Nutr., 15:205-280

Ehsan, E.B.; Naeem, Z.P.; Ghafoor, A. and Bahtti, M.S. (2002). Development, standardization and storage studies on watermelon lemon jam. Pakistan Journal of Food Science, 12 (3-4): 21-24.

Francis, F.J. (1980). Colour quality evaluation of horticultural crops. Horti. Science, 15: 58-59.

Fraser, P.D.; Truesdale, M.R.; Bird, C.R.; Schuch, W. and Bramley, P.M.(1994). Carotenoid biosynthesis during tomato fruit development' evidence for tissue-specific gene expression. Plant Physiology, 105, 405-413.

Giovannucci, E. and Clinton, S.K. (1998). Tomatoes, lycopene, and prostate cancer. Proc. Soc. Exp. Biol. Med., 218:129- 139.

Giovannucci, E.; Ascherio, A.; Rimm, E.B.; Stampfer, M.J.; Colditz, G.A. and Willett, W.C. (1995). Intake of carotenoids and retinol in relation to risk of prostate cancer. J Natl Cancer Inst 87:1767-1776.

Hart, D.J. and Scott, K.J. (1995). "Development and Evaluation of an HPLC Method for the Analysis of Carotenoids in Foods, and the Measurement of the Carotenoids Content of Vegetables and Fruits Commonly Consumed in the UK," Food Chemistry, Vol. 54, ( 1): 101-111.

Hoober, J. K. (1984). "Chapter 3: Carotenoid Pigments," In: Chloroplasts, Plenum Press, New York, p. 57.

Howard, L.R. and Dewi, T. (1995). Sensory, microbiological and chemical quality of mini-peeled carrots as affected by edible coating treatment. Journal of Food Science, 60(1): 142-144. 
Iftikhar, S.; Yasser, D.; Imtiaz, H.; Ihsan, M.Q. and Alam. Z. (2007). Physicochemical analysis of apple and pear mixed fruit jam prepared from varieties grown in azad jammu and kashir. Internet Journal of Food Safety, (9): 22-24

Imaida, K.; Tamano, S.; Kato, K.; Ikeda, Y.; Asamoto, M.; Takahashi, S.; Nir, Z.; Murakoshi, M.; Nishino, H. and Shirai, T. (2001). Lack of chemopreventive effects of lycopene and curcumin on experimental rat prostate carcinogenesis. Carcinogenesis, 22:467-472.

Imtiaz, H. and Iftikhar S. (2010). Chemical and organoleptic characteristics of jam prepared from indigenous varieties of apricot and apple. World Journal of Dairy and Food Sciences, 5(1):73-78.

Jawaheer, B.; Goburdhun, D. and Ruggoo, A. (2003). Effect of processing and storage of guava into jam and juice on the ascorbic acid content. Plant Foods for Human Nutrition, 58: 1-12.

Khachik, F.; Carvalho, L.; Bernstein, P.S.; Garth, J.; Muir, D.Z. and Katz, N.B. (2002). Chemistry, distribution, and metabolism of tomato carotenoids and their impact on human health. Experimental Biology and Medicine, 227, 845-851.

Kong, K.W.; Khoo, H.E.; Prasad, K.N.; Ismail, A.; Tan, C.P. and Rajab, N.F. (2010). Revealing the power of the natural red pigment lycopene. Molecules, 2010: 15 (2): 959-987.

Marti'nez-Valverde, I.; Periago, M.J.; Provan, G. and Chesson, A. (2002). Phenolic compounds, lycopene and antioxidant activity in commercial varieties of tomato (Lycopersicum esculentum). Journal of the Science of Food and Agriculture, 82: 323-330.

Paetau, I., Khachik, F., Brown, E.D., Beecher, G.R., Kramer, T.R., Chittams, J., Clevidence, B.A., 1998. Chronic ingestion of lycopenerich tomato juice or lycopene supplements significantly increases plasma concentrations of lycopene and related tomato carotenoids in humans. American Journal of Clinical Nutrition, 68: 1187-1195

Raffo, A.; Leonardo, C.; Fogliano, V.; Ambrosino, P.; Salucci, M.; Gennaro, L.; Bugianesi, R.; Giuffrida, F. and Quaglia, G. (2002). Nutritional value of cherry tomatoes (Lycopersicon esculentum Cv. Naomi F1) harvested at different ripening stages. Journal of Agricultural and Food Chemistry, 50: 6550-6556.

Ranganna, S. (1979). Manual of analysis of fruit and vegetative products, tata McGraw-Hill publ. Co. Ltd., New Delhi, p. 634. 
Schieber, A., Fügel, R. and Carle, R., (2005). Quality and authenticity control of fruit purees, fruit preparations and jams-a review. Trends Food Sci. Technol. , 16: 433-441.

Siler, U.; Herzog, A.; Spitzer, V.; Seifert, N.; Denelavas, A.; Hunziker, P.B.; Barella, L.; Hunziker, W.; Lein, M.; Goralczyk. R. and Wertz, K. (2005). Lycopene effects on rat normal prostate and prostate tumor tissue. J. Nutr., 135:2050S-2052S.

Snedecor, G.W. and Cochran, W.C. (1980). "Statistical Methods". ${ }^{7}$ th edition, Iowa State Univ., Press, Ames, Iwoa, USA.

Sogi, D.S. and Singh, S. (2001). Studies on bitterness development in kinnow juice ready to serve beverage squash and candy. Journal of Food Science Technology, 38(5): 433-438.

Vinson, J.A.; Dabbagh, Y.A.; Mamdouh, M.S. and Jang, J. (1995). Plant flavonoids, especially tea flavonols are powerful antioxidants using an in vitro oxidation model for heart disease. Journal of Agricultural and Food Chemistry, 43: 2800-2802.
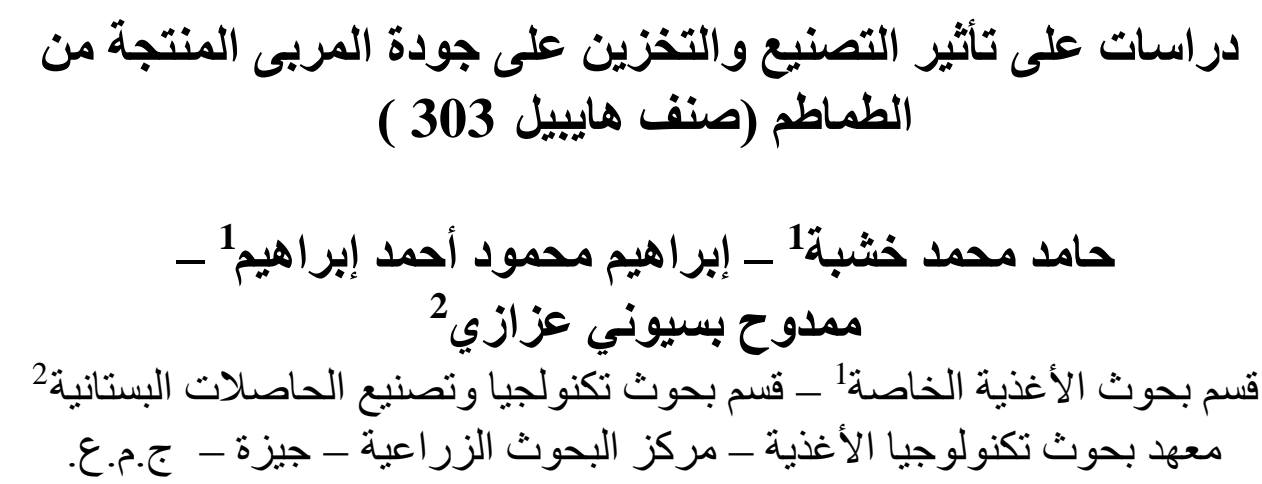

$$
\begin{aligned}
& \text { أظهرت الدر اسات الطبية أن الطماطم ومنتجاتها لهم تأثير ات وقائية ضد تطور } \\
& \text { بعض الأمر اض المزمنة. حيث تحتوي الطماطم علي جزيئات نشطة حيوياً مثل }
\end{aligned}
$$

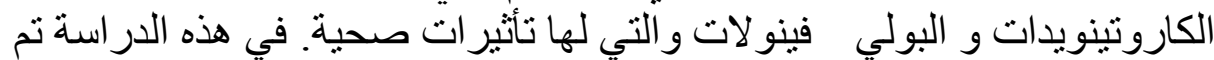

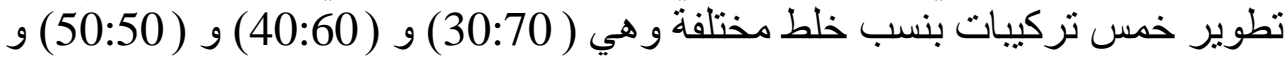

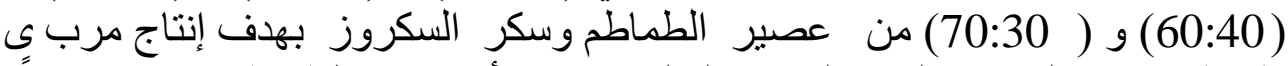

$$
\begin{aligned}
& \text { طماطم تتميز بالجودة والقيمة الغذائية العالية ـ حيث أن مربى الطماطم لاتنتج تجارياً }
\end{aligned}
$$


في مصر . تم قياس مؤشرات الجودة الكيميائية و الحسية لعينات المربي المنتجة (المو اد اد الئات

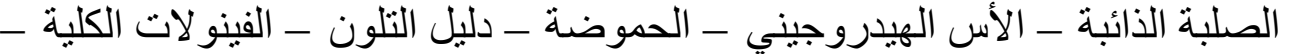

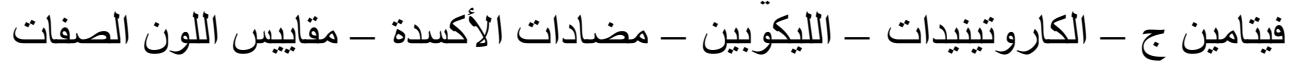

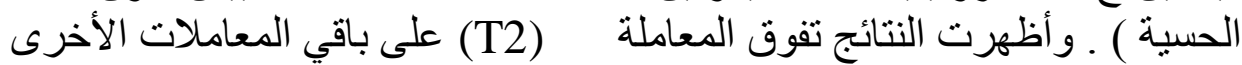

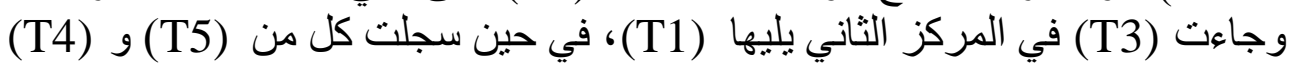

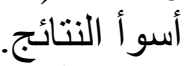
التوصية: خلصت الدر اسة إلى ضرورة إ عطاء الاهتمام لزيادة إنتاج مربى الطماطم

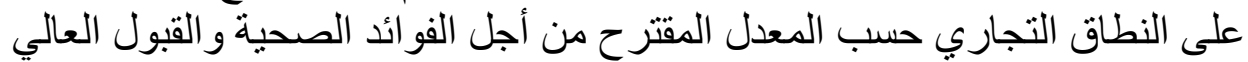

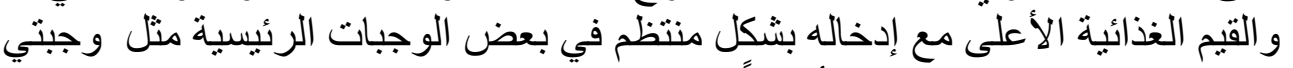

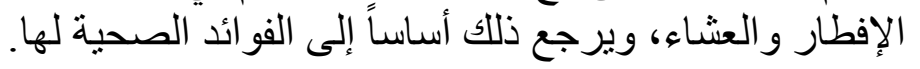

